\title{
Goals of the Monetary Policy and the Stability of the Purchasing Power of Money
}

\author{
Doc. Dr. Neritan Turkeshi
}

Samet Rexhepi, MBA

Rami Ibishi, MBA

\author{
Doi:10.5901/ajis.2015.v4n2p533
}

\begin{abstract}
Theoretical thought in regard to the question of role and the importance of the monetary policy up to the present historical development is characterized with evolutional development of the views and stands of the most important bearers of the scientific thought in the area of the monetary theory. Their views and stands on the most important monetary issues are not always the same or identical. Their differences in the scientific views and opinions are understandable, if you consider the actuality of that problem in its historical (time) dimension on one side, as well as in dependency on the value which is given to the monetary factors on the other side. From historical point of view, the evolutional path of development of the monetary theory is connected or conditioned by the development in the usage of money, as well as the increase of the functions of the money.
\end{abstract}

\section{Introduction}

The most important issues in the area of monetary theory, for which the views and the opinions of the most significant carriers of scientific thought are equivalent, do diverge, and often have opposed opinions on the issues related to money, i.e. the amount of money in circulation, the value of money, the functions of money and the issue on the influence of money on real economic trends. There are different, basically opposed views and opinions, regarding the mentioned issues in the monetary theory. According to ones, the development and changes of the real economic processes and trends are dependent on the factors of production, i.e. labour and the capital and the height of the interest rates, so the changes on the amount of money in circulation have no impact on real economic trends, neither on the height of interest rates, consumption, investment etc. According to other theorists, money have certain impact on the real economic trends, but only then, when the monetary balance is impaired, i.e. when the demand of money differ from the offer of money. In conditions of monetary balance, according to them, the monetary factors have no impact on the real economic trends. The reasons due to which the influence of the amount of money in circulation is relatively minor on the real economic trends are that the amount of money adjusts on its own, with the purpose to respond to the needs of trade, so the amount of money as a variable category gets down to the role of passive element in the development of the monetary cycle. If we agreed on the issue, that the role of the amount of money is passive, then it's needed to identify some other variable which have an active role and impact on the changes (disorders) of the economic balance. According to the representatives of the third group of theorists, the money as a monetary instrument has a key role, or impact on the development and changes of the real economic trends. Every change of the amount of money in circulation in direction to its increase or decrease causes appropriate changes on the real economic trends. As arguments for confirmation of their views and opinions they point out that: the change of the amount of money in circulation can cause major oscillations in the economic activities; the relation of the money toward the rest of the active assets of economic subjects is relatively stable, so the change of the amount of money can have relatively predictable effects on the economic trends; the amount of money in circulation is a monetary aggregate, and it can be controlled with a satisfactory accuracy with the measures of monetary policy.

The basic task of the monetary authority, i.e. the Central Bank of each country, is through the mechanism of money and loans to secure maintenance of the price stability in the country, with the maintenance of the stability of purchasing power of the money in the domestic market, as well as stability of the intercurrence value of the domestic currency, respectively the maintenance of the stability of the exchange rate of the national currency in the intercurrence market. The Central Bank successfully conducts this task, if its reactions, through manipulation with the monetary factors (money and loans), will successfully follow the real economic movements (changes), and accordingly to those changes, 
to establish the necessary balance between them and the monetary factors. Depending on that fact, when and how will monetary authorities react (with increase or decrease of the offer of money), will depend the new price stability, and with that the macroeconomic stability in one country.

The goals of the monetary policy are mostly divided into:

- Basic monetary goals.

- Additional monetary goals.

The accomplishment of the basic and additional goals of the monetary policy is conditioned by the impact of the monetary factors in achievement of the required level of stability.

Beside the division into basic and additional goals of the monetary policy, in the literature can also be met the division into:

- Direct goals of the monetary policy;

- Indirect goals of the monetary policy;

Basic condition to accomplish the goals of the monetary policy is to achieve price stability. Under maintenance of the price stability with the impact of the monetary factors, i.e. the money and the loans, it means ${ }^{1}$ :

- maintenance of a general low level of prices, i.e. low rate of inflation;

- low rate of inflation is a significant assumption for a quality and sustainable economic growth and development;

- the price stability is also one of the assumptions to maintain the stability of the domestic currency.

Following of the movements (changes) of the real economic trends through the monetary factors, i.e. with the adequate change of the monetary factors (money and loans) will provide maintenance of the current balance in the frames of one economy. But, it's hard to keep the balance in the practice, especially in long term; therefore it's necessary to continually adjust the offer of the monetary factors according to the changes of the real economic trends.

The changes in the offer of money, whether it's about increase or decrease of the offer of money, it affects not only the price stability, but also the level of the interest rates, the employment, the investments and the level of the effective GDP. How the impact of the changes in the offer of money on the most important macroeconomic aggregates, i.e. upon the interest rates, employment, investments and the effective GDP, depends also from the phase of the economic cycle in which is the economy of one country. Due to the connection between the amount of money in circulation and the rate of growth of the prices (inflation) in one economy, the Central Bank is considered as a guardian of the prices in the modern economies (N.Gregory Mankiw, Mrk P. Taylor, Economics, translated SP Print-Belgrade, 2008, page 594.). The changes in the offer of money, in essence means change of the monetary policy in one country.

\section{Basic Elements of the Monetary Policy}

Through the system of the monetary factors, the monetary authority influences on the accomplishment of the basic and other goals of the monetary, and to the macroeconomic policy. The manipulation with the financial mass is in direction to adjustment of the amount of money in circulation with the needs of the economic trends on one side, as well as the need of initiation of the development of economic cycle with the help of the monetary factors, in the other side. Also, the monetary factors can be used as initial value (category) which can cause and produce changes in the trend and the dynamic of development of the economic trends. Beside for the so-called pure monetary goals, the monetary policy is also in the function of accomplishment of the goals of macroeconomic policy, i.e. securing a higher rate of economic growth, increase of the rate of employment and maintaining the macroeconomic stability in the country. The impact of the monetary policy in accomplishment of the goals of macroeconomic policy is indirect. The so-called direct goals or intermediate goals of the monetary policy have the role as mediators, transferors respectively through whom the impact is accomplished (Dr. Ljupcho Trpeski, Monetary economy, Skopje, 2010, page 232.). In the group of the basic goals of the monetary policy are included: securing of economic liquidity, monetary balance, maintenance of stability of the purchasing power of money and maintenance of stability of the exchange rate of national currency.

\subsection{Economic liquidity}

In the group of basic goals of the monetary policy is also the providing of the required level of liquidity in the frames of

${ }^{1}$ Academic Taki Fiti, Economy, Economic faculty, Skopje, 2008, page 430. 
one national economy. The accomplishment of this goal of the monetary policy is under the jurisdiction of the monetary authority, i.e. the Central Bank as a highest monetary authority in one country. Economic liquidity refers to the condition of national economy in which the monetary authority distributes or enables distribution of the required amount of monetary factors (money and loans) which would be sufficient for a successful functioning of the economy, as well as successful accomplishment of the projected goals of the macroeconomic policy of the country.

The accomplishment of this basis goal of the monetary policy is narrowly connected with the emission policy, i.e. the policy of primary money and the credit policy. Which strategy will be implemented in accomplishment of this goal depends on the level of development of financial market and the approach in monetary regulation. Countries with developed financial market as an operative target for monetary regulation use the interest rates as one of the basic instruments of monetary policy, while the countries with a lower level of financial market use the mechanism of primary money as an operative target for monetary regulation. In the first case, through the change of level (amount) of interest rate it's affected on the amount of monetary factors, respectively on the amount of money in circulation, while in the second case, the monetary regulation, i.e. the amount of money in circulation is determined upon the so-called policy of primary money. The practice in numerous countries shows that, the Central Bank through the manipulation with the interest rate successfully manages to implement the process of monetary regulation. Sensitivity of the change of interest rates is higher in the countries with developed financial market in relation to the countries with a lower level of development of financial market.

\subsection{Monetary balance}

One of the basic goals of the macroeconomic policy, and in those frames of the monetary policy is to secure stabile macroeconomic conditions of action. Such conditions are secured if the monetary funds are in balance with the commodity funds. Each deviation from the balance in direction of increase or decrease of the monetary (financial) funds in relation to commodity funds causes a condition of instability of the macroeconomic ambient for action.

While implementing the monetary policy, of a special importance is to determine the rate of the monetary growth. Several methods are known in the monetary theory, ways to determine the rate of the monetary growth:

$\rightarrow$ The method of targeting the monetary growth;

$\rightarrow$ Method of targeting the rate of inflation;

$\rightarrow$ Through leading a tight monetary policy;

$\rightarrow$ Through a complete independence of the Central Bank.

On targeting the monetary growth, the Central Bank publishes the rate of growth of the offer of money. In principle, the targeted rate is in that way determined, so it can be maintained on the level which suits the predicted rate of inflation and the real rate of economic growth of the economy of one country. The appliance of the targeted rate of monetary growth was used during the 70's and the 80's of the last century. The method of targeting the monetary growth started to be used in the USA in 1975 when the Federal Reserve's of the USA (FED) published the targets of the three most important monetary aggregates (M1, M2 and M3), but due to the difficulties in implementation of the control of monetary growth, they faced with failures of the targets of monetary growth. As a reason for abandoning the method of targeting the monetary growth in the USA, are considered the sudden changes in the financial system in the USA during the 70's and the 80's of the last century, which caused serious difficulties in predicting the demand of money.

The method of targeting the rate of inflation started to implement in 1990, firstly in New Zealand and later in other countries. With this model, the Central Bank is obliged to publish the rate of inflation as the ultimate goal which needs to be achieved in the period of four years. It is considered that the method of targeting the inflation successfully solves the problem of predictions of the demand of money. According to this model, if the demand of money is unstable, i.e. it changes, and then the Central Bank can react with adequate change of the offer of money. Still, the biggest deficiency of the model of targeting the inflation is considered the time delay of the effects upon the inflation by the measures of the Central Bank.

Beside the method of targeting the monetary growth and targeting the inflation, there are other methods, ways to determine the monetary growth, and with that the increase of the effects by the appliance of the measures and the instruments of the monetary policy. As a way to achieve this goal is considered the insertion of a banker with a strong hand who is prepared to conduct the outlined policy of tight hand. Such was the case with the appointment of Paul Walker as Chairman of FED in the USA (Andrew B. Abel, Ben S. Bernanke, macroeconomics, United States-Economic conditions,2001 translated in Macedonian,). He managed to solve the problem of high rate of inflation in the USA, but because of his inflexibility in managing the monetary policy, the rate of the unemployment in the USA increased, 
especially in the period between 1981 and 1982.

As a model, way to regulate the monetary growth also is considered the increase of the independence of the Central Bank in leading the monetary policy. In the countries in which the Central Banks are independent from the executive authority, they lead an independent monetary policy, run according to the determined goals of the monetary policy. The monetary growth in those countries is determined and conducted according to the changes in the real economic trends, without any influence or pressure, especially from the executive authority.

\subsection{Maintenance of the stability of the purchasing power of money}

The role of the Central Bank in maintaining the stability of the purchasing power of money is of a first degree importance. The stability of the purchasing power of the money refers to a condition when the value of money is not changing, respectfully when the variations (changes) of the value of money are moving in the margins (limits) anticipated with the monetary policy. The stability of the purchasing power of money is possible only if the purchasing funds in one economy are equal with the commodities funds, more precisely when the commodities and monetary funds are in balance. The market of money is in balance when the offer of money, determined by the Central Bank is equal with the aggregate demand of money (total demand of money) (Paul R.Krugman, Maurice Obstfeld, International Economics, Pearson Education, 2009, предевено на македонски јазик, 2010, стр. 372).

The monetary authority, i.e. the Central Bank concerns about the stability of the purchasing power of the money. If the Central Bank release a larger amount of money in circulation, then it comes to a rise of the general level of the prices, decrease of the interest rates and the decrease of the purchasing power of the money, because with the same amount of money a smaller amount of goods and services can be bought. If the Central Bank through the emission policy releases a smaller amount of money in circulation, then by rule it comes to a decrease of the general level of the prices, increase of the interest rates, decrease of the investments but also to the increase of the purchasing power of money, which means that with the same amount of money a larger amount of goods and services can be bought.

Under jurisdiction of the Central Bank is also the maintenance of the stability of the purchasing power of money. With the measures and the instruments of the monetary policy, the Central Bank is in position to affect the amount of money in circulation, and with that to affect the stability of the purchasing power of money. Depending on the condition of the national economy and the goals of the macroeconomic policy, and in those frames the goals of the monetary policy, the Central Bank conducts an expansive, restrictive or neutral monetary policy.

The total amount of money in circulation in one country is determined by (Трпески Др.Лупчо, Монетарна Економија, Скопје, 2010, стр. 279.):

- the primary emission of money, which appears in the form of obligations of the Central Bank towards other sectors of the economy;

- the credit expansion of the deposits. The deposition banks are the only institutions capable to multiply the deposits which are deposited at them.

By previously stated it means that the total amount of money in the frames of one national economy depends on the monetary mass and the monetary multiplier. Having in mind the fact the total monetary mass in the frames of one national economy depends on the policy which is implemented by the monetary authority, than we can conclude that the maintenance of the stability of the purchasing power of money is under direct influence of the policy of the monetary authority.

\subsection{Maintenance of the stability of the exchange rate of national currency}

Maintenance of the stability of the exchange rate of national currency is also under the jurisdiction of the Central Bank. Independently which regime of the exchange rate is implemented in determination of the intercurrence value of the national currency, it's of an interest of each country to achieve stability of the exchange rate of national currency. The exchange rate of national currency can be:

- Fixated exchange rate;

- Variable or floating exchange rate;

- Exchange rate determined upon the so-called exchange rate of a basket of currencies.

The stability of the exchange rate of national currency means a condition in which the value (price) of the national currency expressed in foreign financial units remains unchanged, respectively when the fluctuations of the value of domestic currency expressed in foreign financial units are in the frames of the projected values. Maintenance of the 
stability of the exchange rate of national currency can be achieved also in the three current regimes of the exchange rate, with the difference that during the fixated regime of the exchange rates, the intercurrence of the national currency is fixated on one determined level, while in the regime of fluctuated (floating) rates, the intercurrence value of the national currency fluctuates depending on the offer and demand of the foreign financial units (currencies and foreign currencies) in the domestic market. In the regime of the so-called basket of currencies, the intercurrence value of the national currency, and with that the stability of the exchange rate of national currency depends on the level of fluctuations of the value of chosen basket of currencies in the intercurrence market. All these previously mentioned regimes of the exchange rates have positive effects but they also cause certain negative implications on the condition and the development of the national economies.

\section{Additonal Goals of the Monetary Policy}

As is already known, the ultimate goal of the monetary policy is the accomplishment of the ultimate goals of the macroeconomic policy; such are the increase of the rate of economic growth, increase of the rate of employment and creation of stabile macroeconomic conditions, i.e. the stability of prices and a stable exchange rate of the national currency. The importance of the monetary policy in this domain is in the efficient functioning of the monetary system, while through creation of stable monetary conditions, to affect the accomplishment of the goals of macroeconomic, and with that to the monetary policy. To accomplish the projected goals of the macroeconomic and monetary policy, beside the basic instruments of the monetary policy, the Central Bank also uses additional instruments. In the group of additional instruments of the monetary policy are: selection of the targeted intermediate variable, the use of the monetary aggregates as intermediate goals, the use of the interest rate as the intermediate goal of the monetary policy, as well as other variables as possible intermediate goals of the monetary policy.

\subsection{Monetary aggregates as intermediate goals}

Last several decades, the economists of the most developed countries have shown preference towards the monetary aggregates as intermediate goal of the monetary policy. Particularly was implemented the policy of programming of the growth of monetary aggregates on a year basis. As important elements (factors) which affected upon the decision to approach toward yearly targeting of the monetary aggregates were:

- the problems with which the economies of the highly developed countries faced, with the use of the minimal interest rates in conditions of increase of the rate of inflation and inflationary expectations;

- the growth of the rate of inflation and inflationary expectations have caused fall of the real interest rates, beside the fact that the nominal interest rates remained the same, or they grew;

- the real interest rates were accepted as significant variables while bringing the decision about the level of consumption by the economic subjects.

The explanation was that if to a change of the interest rates have come as a consequence of the growth of aggregate demand, and then the growth of the interest rates can give a misconception about the character of the monetary policy. In order to learn the reasons for the rise of the interest rates, i.e. is the reason the character of the monetary policy (expansive or restrictive), they have pointed out on the need to follow the changes of the interest rates, but also to the other variables, and such are: the reserves of liquid funds and the financial mass in circulation.

\subsection{The interest rate as a intermediate goal of the monetary policy}

The nominal and real interest rates are a long term intermediate goals of the monetary policy. In the literature of the monetary policy can be found different views and stands in regard to the relation between the interest rates and the ultimate goal of the economic policy (growth of the GDP) as well as that the connection between the interest rates and the inflation is unclear and weak, and even false (Dr. Aleksandar Zhivkovic and Dr. Gradimir Kozhetinac, Monetary economy, Economic faculty-Belgrade, 2005, page 304). In those conditions, the impact of the Central Bank in regulation of the interest rates through the instruments of the monetary policy is limited, therefore in the developed market economies, the interest rates don't serve (use) as the only target of the monetary policy, but primarily are used the monetary aggregates as intermediate goals of the monetary policy. But, from the numerous researches it's concluded that the impact of the real interest rates on the real economic trends is significant.

The amount of the interest rates primarily depends on the state of the economy in one country. When the economy 
is in balance, then the interest rate is natural and is a reflection of equalling the desire for saving and the investments. But, the amount of the interest rate is not always on the level of the natural interest rate, i.e. higher or lower of the natural interest rate, depending on the condition of the economy and the measures of the macroeconomic, and especially the monetary policy. The growth of the interest rate should be the signal to the monetary authority for appropriate reaction, in order to change the condition or to change the approach in implementation of the monetary policy. The growth of the interest rates not only does narrow the space for acceleration of the economic trends, but also gives enough of information about the real condition in one national economy. Therefore, according to the research conducted in the USA, it turns out that the best approach regarding the monetary targeting is in the use of this information about the movement of the interest rates as informational variables. This dual approach of monetary targeting implies on the importance which is given to the monetary aggregates and the interest rate as intermediate goals of the monetary policy. In regard to the issue of the intermediate goals of the monetary policy, James Tobin concludes that the economy which has a complicated financial structure, where the instruments of the monetary policy can be replaced with each other, it is difficult to separate some of the financial aggregates, or the interest rate as a variable which has the direct connection with the real economic trends.

\section{Conclusion}

Monetary policy, as part of the overall macroeconomic policy of one country has a great impact on the overall socioeconomic and social development, and in this framework and the development of the banking sector of a country;

The impact of the monetary policy on the changes of real economic flows on one hand, and the impact on the stability of the financial system, and thus the monetary flows, on the other hand, is in the function of stimulating the overall economic and social development, and within this framework the development of the banking sector. Through the application of measures and instruments of the monetary policy it seeks to sustain the price stability as the ultimate goal of monetary policy, while through the mechanism of monetary regulation, the stability of the purchasing power of money in the internal market and exchange rate stability of the national currency;

The impact of monetary policy, and efficiency in the use of the instruments of monetary policy in realizing its goals, as well as the objectives of macroeconomic policy, depends on the degree of autonomy of monetary authorities on one hand, and the level of coordination of its activities with other organs and institutions of the system, on the other hand;

Depending on the situation in one national economy (the level of economic development, levels of monetarism of the economy, and the phase of economic cycle which passes through a country's economy), on one hand, and the objectives of macroeconomic policy, within this framework the objectives of the monetary policy, the monetary authority leads an expansive, restrictive or neutral monetary policy;

\section{References}

Gilbert, A, A revision in the Monetary Base, (The Federal Reserve Bank of St. Luois, 1987, August - September).

Smith, G., "Money and Banking" (New York, Addisia Wesley Publishing Company),1982.

Prevalla, Sh., Finansiranje na biznisot, (Skopje, Akademik izdanie), 2005

Bishev, G., Nenovski, T., "Rendi financiar dhe bankat", NAM - Shkup, 1995.

Zhivkovic, A., Kozhetinac, G., Monetary economy, Economic faculty, Belgrade, 2005.

Krugman, P., Obstfeld, M., International Economics, Pearson Education, предевено на македонски јазик, 2009, стр. 372.

Abel, A., Bernanke, B., 2001, Macroeconomics, United States-Economic conditions, Translated in Macedonian, 2010, page 593.

Трпески Др.Лупчо, Монетарна Економија, Скопје, 2010, стр. 279.

Academic Taki Fiti, Economy, Economic faculty, Skopje, 2008, page 430.

Mankiw, G., Taylor, M., Economics, translated SP Print-Belgrade, 2008, page 594. 